\title{
Germination responses of the Rubia fruticosa Ait. seed dispersal system in different experimental seasons
}

\author{
A. Rodr'iguez, M. Nogales* and C. Nieves \\ Island Ecology and Evolution Research Group (IPNA-CSIC), Avda. Astrofísico Francisco Sánchez 3, 38206 La Laguna, Tenerife, Canary \\ Islands, Spain
}

\begin{abstract}
In this paper, we present results on germination patterns of the seed dispersal system of an endemic Macaronesian plant (Rubia fruticosa). Seeds from this plant are mainly dispersed by endemic lizards and native warblers; therefore, we included three different treatments: control seeds, seeds extracted from lizards and seeds found in warbler droppings. Seeds from the same pool of every treatment were germinated in two different seasons, one in autumn, coinciding with the arrival of the first rains, and another in spring, coinciding with the arrival of the dry season. A clear differential pattern of germination success was observed between the two seasons. Seeds planted in autumn achieved a higher percentage of germination than those sown in spring in all treatments. The great robustness of these results seems to indicate that germination timing is strongly selected in R. fruticosa and this evolutionary trend probably extends to other vascular plants growing in xeric coastal environments of the Macaronesian islands.
\end{abstract}

Key words: Rubia fruticosa, seed dispersal, germination timing, Macaronesian islands

\section{Résumé}

Dans cet article, nous présentons les résultats concernant les patterns de germination du système de dispersion des graines d'une plante endémique des îles Macaronésiennes (Rubia fruticosa). Les graines de cette plante sont principalement dispersées par des lézards endémiques et des fauvettes locales. C'est pourquoi nous avons adopte' trois traitements différents: des semences de contrôle, des semences extraites des lézards et celles trouvées dans les

*Correspondence: Tel.: +34 922260190 (ext. 281); Fax:

+34 922 260135; E-mail: mnogales@ipna.csic.es crottes des fauvettes. Les semences qui provenaient de la même origine étaient mises à germer dans deux saisons différentes, en automne, ce qui correspond à l'arrivée des premières pluies, et au printemps, au début de la saison sèche. On a observé un pattern de germination clairement différencié entre les deux saisons. Les semences plantées en automne avaient un pourcentage de germination plus élevé que celles plantées au printemps, quel que soit le traitement d'origine. La solidité de ces résultats semble indiquer que le timing de la germination est fermement choisi chez $R$. fruticosa, et cette tendance évolutive s'étend probablement aux autres plantes vasculaires qui poussent dans les environnements xériques des îles Macaronésiennes.

\section{Introduction}

Plant species have a characteristic germination season or seasons, and the time of year when germination is possible is limited for many species (Rathcke \& Lacey, 1985; Baskin \& Baskin, 2001). The environmental conditions of each habitat modulate the optimal season in which seeds present greater germination and seedling survival rates (Donohue et al., 2005). This phenological trait has probably been subjected to strong selection pressure, as occurs with other related ecological aspects such as early seed germination (Geber \& Griffen, 2003) being especially important for those plant species that inhabit arid environments (Gutterman, 1993; Whitford, 2002) where rainfall is restricted to a certain season of the year. Despite the logical approach of this evolutionary trend, as far as we know, no study has been performed on this topic while addressing a whole seed dispersal system (see Traveset, 1998). Therefore, one of the most important factors that should be taken into account in seed germination experiments is the phenology of the seed phase. Thus, in order to test the potential differential results of germination in dif- 
ferent seasons of the year, we have chosen Rubia fruticosa Ait. (Rubiaceae) as a model. This species is an endemic plant that inhabits the xeric habitats of the Macaronesian islands of Madeira, Salvages and the Canaries. Its main distribution is in the coastal zones and is relatively abundant in all the main Canary Islands. Rubia fruticosa (approximately 0.5-1 m plant cover) can reach $1.5 \mathrm{~m}$ in height and produces numerous translucent fruits (for further details, see Nogales et al., 2001). In order to evaluate the seed germination response within a complete ecological framework, seeds from the three main treatments involved in this seed dispersal system were included. Thus, seeds were collected and depulped from control plants and extracted from main seed disperser droppings, which included those of lizards of the genus Gallotia (Lacertidae) and some warbler species (genus Sylvia) in the Canarian archipelago (Nogales et al., 2005). It is important to note, that in a review using meta-analysis carried out by Traveset \& Verdú (2002), the general effect of gut treatment tends to enhance the germination percentage of seeds and, dispersers can also induce germination asynchrony (Izhaki \& Safriel, 1990; Nogales et al., 2006).

The main objective of this short experimental study was to determine the possible differential effects of the sowing date on seed germination, for the seed dispersal system of $R$. fruticosa. For this purpose, we performed two different seasonal experiments: one in autumn, which is theoretically more favourable because it coincides with the arrival of the first rains in the Canaries (wet season: autumn and winter) and seed germination, and another theoretically less advantageous, which coincides with the start of the dry period (dry season: spring and summer) (Garc'ia et al., 2001).

\section{Material and methods}

To control differential mother effects on seed germination in the different populations of $R$. fruticosa, seeds were collected from the main treatments (control plants, and droppings of lizards and warblers) in a reduced zone $\left(4000 \mathrm{~m}^{2}\right)$ of the Malpa's de La Corona (Northeast Lanzarote, Canaries: $27^{\circ}-29^{\circ} \mathrm{N}$ and $13^{\circ}-18^{\circ} \mathrm{W}$ ). This area consists of a xeric badland (hereafter malpa'ss) where annual rainfall is low $(157.8 \pm 80.6 \mathrm{~mm})$ and the mean temperature is $21 \pm 0.60^{\circ} \mathrm{C}$. The climate is strongly influenced by dry Sahara winds due to the proximity of Africa (approximately $130 \mathrm{~km}$ at the closest point). Vegetation composition consists of sparse xeric shrub composed mainly of Euphorbia regis-jubae, E. balsamifera, Launaea arborescens, Kleinia neriifolia, Lycium intricatum, R. fruticosa and Asparagus spp.

The material (seeds and droppings) was collected during the spring seasons of 2003-2004, and the same stock of seeds (seed sample sizes were balanced between the two years and treatments) was randomly used to perform the germination experiments. We were forced to collect seeds in these two consecutive years, due to the limited availability in the natural area. Seeds were stored in a dry place in the dark and at room temperature. Two different experiments were carried out: one in autumn (1 October 2004) and another in spring (11 April 2005). Seeds (200 per treatment in autumn, and 230 in spring) were each planted separately in a $4 \mathrm{~cm}^{2}$ pot, using a standard substrate $(50 \%$ culture soil, $25 \%$ turf and $25 \%$ volcanic sand). The germination experiment was then performed in a greenhouse in order to control the same environmental conditions. The duration of the experiment was one and a half months because most seeds germinate within this period (see Nogales et al., 2001, 2006). Each seed was buried to a depth of about $5 \mathrm{~mm}$ and watered every 2 days; germination was considered to be the emergence of any seedling part from the soil. Data were taken every 5 days and likelihood ratio tests were employed to evaluate differences in the percentage of seed germination in each different treatment (control, lizard and birds). Furthermore, in order to evaluate the overall effect of treatments (control, lizards and warblers) and experimental seasons simultaneously (autumn and spring), we employed a General Lineal Model (GLM) analysis. Statistical inferences (Kolmogorov-Smirnov tests) on seed emergence rate (speed of germination) could not be performed due to the low rate of germination recorded in the spring experiments and the rapid stabilization of seed emergence, which limited the sample sizes and therefore the subsequent replicates. Analyses were performed using the SPSS program statistical package (version 12.0; SPSS Inc., Chicago, IL, U.S.A.).

\section{Results and discussion}

A clear differential pattern of germination success can be observed between the two seasons in all different treatments (control: $G_{1} 1 / 4$ 104.8, $P<0.001$; Gallotia: $G_{1} 1 / 4$ 77.1, $P<0.001$; and Sylvia: $\left.G_{1} 1 / 481.7, P<0.001\right)$. These data indicate that seeds planted in autumn achieved a higher percentage of germination than those sown in spring in all treatments. The same results were 


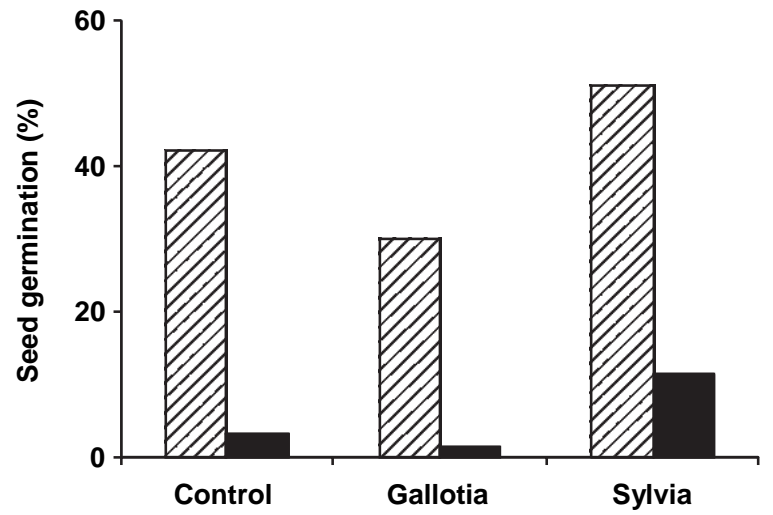

Fig 1 Germinated seeds of Rubia fruticosa in two different seasonal experiments. Line bars: autumn, black bars: spring

obtained when GLM analysis was performed and only significant differences were appreciated with respect to seasons $\left(F_{1,2} 1 \frac{1}{4} 82.35, P 1 / 40.012\right)$. The great robustness of these results seems to indicate that germination timing is a strongly selected trait in $R$. fruticosa and this evolutionary trend probably extends to other vascular plants growing in xeric environments. It is also important to consider that seedling emergence is one of the most crucial phases in the life cycle of plants because it determines plant performance and success (Harper, 1977). Furthermore, in both seasonal experiments, the same pattern can be observed in the seed germination percentage from the different treatments (Sylvia, control and Gallotia) (Fig. 1).

The emergence rate at which seeds germinated was apparently faster in spring than in autumn (Fig. 2). Theoretically, seedlings from stressed climatic environments (e.g. xeric habitats) have to emerge rapidly to become vigorous and robust in order to resist the arrival of the selective dry season (see Verdú \& Traveset, 2005; Nogales et al., 2006).

The results obtained in the germination experiments discussed in this work will be useful for future conservation actions for some threatened populations of R. fruticosa in the Macaronesian islands (off north-west Africa). This is the case of Salvagem Grande $(160 \mathrm{~km}$ north of the Canaries), where the plant population has currently been reduced to 40-50 individuals restricted to a marine cliff due to the devastating effects of invasive non-native herbivores. Goats, rabbits and mice were probably present on this small island (approximately $2.5 \mathrm{~km}^{2}$ ) for four or five centuries, causing considerable impoverishment of native flora. Currently, with the absence of goats and the eradication of rabbits and mice (the latter carried out by the Parque Natural da Madeira in 2003; P. Oliveira and

D. Menezes, pers. comm.), this plant may have a promising future.

Finally, other xeric plant species inhabiting the coastal areas of the Macaronesian islands may exhibit the same germination timing pattern, proving important for future germination experiments. The information obtained in this study may be useful for ecologists and conservation practitioners.

\section{Acknowledgements}

Yaiza Sistiaga, Carlos Rodríguez, Javier Triñares and Agustín F. González provided logistical support during the spring 2005 germination experiments. Patricia Marrero and David P. Padilla made a critical review of the manuscript. The Editor (Jon Lovett) and an anonymous referee gave all kinds of useful advice which clearly improved the manuscript. The Cabildo Insular of Lanzarote granted permission to work in this protected area. This study has
Fig 2 Germination rate (number of seeds) of Rubia fruticosa in two different seasonal experiments. Black circles: control, white circles: Gallotia and lines: Sylvia. Number of seeds for both experiments is in a different scale
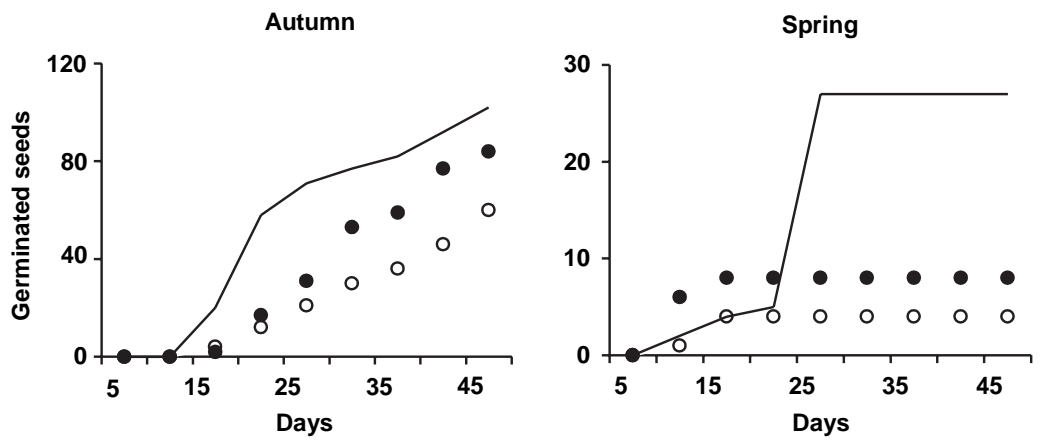
364 A. Rodr'iguez et al.

been carried out within project BOS2003-00044, granted to M.N., and financed by the Spanish Ministerio de Ciencia y Tecnolog'la and the Feder funds from the European Union.

\section{References}

BASKIN, C.C. \& BASkin, J.M. (2001) Seeds Ecology, Biogeography, and Evolution of Dormancy and Germination. Academic Press, San Diego, CA.

Donohue, K., Dorn, L., Griffith, C., Kim, E.S., Aguilera, A., PoliSETTY, C.R. \& Schmitt, J. (2005) Niche construction through germination cueing: life-history responses to timing of germination in Arabidopsis thaliana. Evolution 59, 771-785.

García, R., Gallego, D., Hernández, E., Gimeno, L. \& Ribera, P. (2001) Influence of the North Atlantic oscillation on the Canary Islands precipitation. J. Climate 14, 3889-3903.

GEBER, M.A. \& GRIFFEN, L.R. (2003) Inheritance and natural selection on functional traits. Int. J. Plant Sci. 164, S21-S42.

GutTerman, Y. (1993) Seed Germination in Desert Plants. Adaptations of Desert Organisms. Springer-Verlag, Berlin.

HARPER, J.L. (1977) Population Biology of Plants. Academic Press, New York.

IZHAKI, I. \& SAFRIEL, U.N. (1990) The effect of some Mediterranean scrubland frugivores upon germination patterns. J. Ecol. 78, 56-65.

Nogales, M., Medina, F.M., Quilis, V. \& GonZÁLEZ-Rodríguez, M. (2001) Ecological and biogeographical implications of YellowLegged Gulls (Larus cachinnans Pallas) as seed dispersers of Rubia fruticosa Ait. (Rubiaceae) in the Canary Islands. J. Biogeogr. 28, 1137-1145.
Nogales, M., Nieves, C., Illera, J.C., Padilla, D.P. \& Traveset, A. (2005) Effect of native and alien vertebrate frugivores on seed viability and germination patterns of Rubia fruticosa (Rubiaceae) in the eastern Canary Islands. Funct. Ecol. 19, 429-436.

Nogales, M., Nieves, C., Illera, J.C. \& PAdilla, D.P. (2006) Native dispersers induce germination asynchrony in a Macaronesian endemic plant (Rubia fruticosa, Rubiaceae) in xeric environments of the Canary Islands. J. Arid Environ. 64, 357-363.

RATHCKE, B. \& LACEY, E.P. (1985) Phenological patterns of terrestrial plants. Ann. Rev. Ecol. Syst. 16, 179-214.

TRAVESET, A. (1998) Effect of seed passage through vertebrate frugivores' guts on germination: a review. Perspect. Plant Ecol. Evol. Syst. 1/2, 151-190.

TRaveseT, A. \& Verdú, M. (2002) A meta-analysis of the effect of gut treatment on seed germination. In: Seed Dispersal and Frugivory: Ecology, Evolution and Conservation (Eds D. J. LEVEY, W. R. Silva and M. GaLETTI). CABI publishing, New York.

VERDÚ, M. \& TRAVESET, A. (2005) Early emergence enhances plant fitness: a phylogenetically controlled meta-analysis. Ecology 86, 1385-1394.

Whitford, W.G. (2002) Ecology of Desert Systems. Academic Press, San Diego, CA. 